\title{
TRACE ELEMENT ANALYSIS OF GRANITIC AND RADIOACTIVE ROCKS BY SPARK SOURCE MASS SPECTROMETRY WITH ELECTRICAL DETECTION
}

\author{
Kalervo Nieminen and Inkeri Yliruokanen
}

\begin{abstract}
Nieminen, Kalervo and Yliruokanen, Inkeri: Trace element analysis of granitic and radioactive rocks by spark source mass spectrometry with electrical detection. Bull. Geol. Soc. Finland 46,167-176.
\end{abstract}

The content of 40 trace elements $(\mathrm{Li}, \mathrm{Be}, \mathrm{B}, \mathrm{F}, \mathrm{P}, \mathrm{Cl}, \mathrm{Sc}, \mathrm{Ti}, \mathrm{V}, \mathrm{Co}, \mathrm{Cu}, \mathrm{Rb}$, $\mathrm{Sr}, \mathrm{Y}, \mathrm{Zr}, \mathrm{Nb}, \mathrm{Sn}, \mathrm{Cs}, \mathrm{Ba}, \mathrm{La}-\mathrm{Lu}, \mathrm{Hf}, \mathrm{Ta}, \mathrm{Tl}, \mathrm{Pb}, \mathrm{Bi}$, Th, and $\mathrm{U}$ ) was determined by spark source mass spectrometry in 25 samples from granites and $U$, Th and lanthanoid deposits in South Finland. The scanning method was employed with USGS G-1 and W-1 as external standards. Accuracy was estimated to be better than $\pm 20 \%$ and detection limit was $0.1-10 \mathrm{ppm}$.

Kalervo Nieminen and Inkeri Yliruokanen, Department of Chemistry, Helsinki University of Technology, SF-02150 Otaniemi, Finland

\section{Introduction}

The total trace element analysis of geochemical and geological samples is often useful. Spark source mass spectrometry is one of the most sensitive and comprehensive techniques for determining trace elements in solids. It has been used for the multielement analysis of geological samples by several authors, e.g. Brown and Wolstenholme (1964), Taylor (1965 a), Taylor (1965 b), Nicholls et al. (1967), Carver and Johnson (1968), Graham and Nicholls (1969), Morrison and Kashuba (1969), and Morrison et al. (1970).

All these studies were performed using photoplate detection. Taylor (1965 b) achieved a precision of $10 \%$, Nicholls et al. (1967), who homogenized the samples by fusing them to a glass before the electrode preparation, achieved a precision of $5 \%$. Multielement analysis is, however, very tedious with this method of detection. Electrical detection has been developed to cut out the photographic work and to improve precision. Two different methods are feasible: peak switching when high precision is required on a few selected elements of interest, and scanning when rapid survey with wide element coverage is needed. Bingham and Elliot (1971) reviewed both methods and reported accuracy from 2 to $5 \%$ for peak switching and about $30 \%$ for scanning of metallic samples. Morrison and Colby (1972) studied powdered samples with peak switching; the precision was from 3 to $6 \%$.

The aim of the present study is to examine whether the scanning method could be used for 
the trace element analysis of rock samples. We were content with low precision because more elements could be determined and more samples analyzed with a moderate amount of work. For many problems it is sufficient when the order of magnitude of the trace element abundance is known and very accurate results are not essential.

The samples were taken in southern Finland from granites and known deposits of $\mathrm{U}$, Th and lanthanoids in order to study whether a multielement analysis of this kind could be useful in investigations of the genesis and mineralogy of these deposits.

\section{Sampling sites and samples}

The sampling sites are situated in the province of Uusimaa, South Finland (Fig. 1). Geologically this area belongs to the Svecokarelidic orogenic belt, which is characterized by potash granites. migmatites and metasediments. It is bounded on the east by anorogenic younger rapakivi massif and Onas granite and on the west by Obbnäs-Bodom granites.

The following samples were analyzed from the granitic rocks:

1. Even-grained rapakivi granite from Lapinjärvi containing potash feldspar ovoids mantled by plagioclase; plagioclase, quartz,

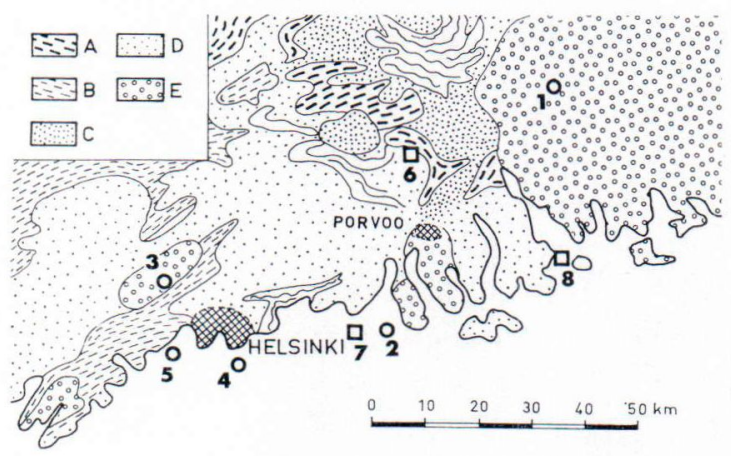

Fig. 1. Sampling sites. (Map based on Geological map of Finland by Ahti Simonen 1959). $1-5$ granites, 6-8 U, Th, and REE deposits. $\mathrm{A}=$ metabasalt, $\mathrm{B}=$ quartz feldspar schists, $C=$ granodiorite and quartz diorite, $\mathrm{D}=$ granite, $\mathrm{E}=$ rapakivi. biotite and hornblende as principal minerals (Laitakari and Simonen 1963).

2. Onas granite (Sederholm 1923). Homogeneous coarse-grained red granite from an old quarry at the southern end of the Onas island.

3. Bodom granite from an old quarry in the village of Hämeenkylä (Härme 1969). Ready-milled homogeneous plagioclase granite from the Geological Survey of Finland.

4, 5. Granites from Kuivasaari and Käärmesaari, respectively (Laitala 1967). They represent less homogeneous, fine-grained potash granites with assimilated fragments of older rocks.

In addition to these granitic rocks, samples were also taken from the following mineralized pegmatite and vein deposits:

6. Askola, Lakeakallio (Laitakari and Simonen 1963). This deposit consists of graniticpegmatitic intrusions surrounded by mica gneiss. The pegmatitic portion contains mainly quartz and red potash feldspar with biotite and dark garnet and molybdenite in some places. The feldspar grains often have hematized surfaces. The granitic portions of the deposit resemble alaskite granites with white feldspar, smoky quartz and black mica. Some parts of the deposit are radioactive owing to uranium-bearing mineral inclusions, but the mineral assembly has not yet been worked out. A pilot plant for ore dressing was in operation from 1957-1959, but the deposit proved to be economically non profitable. The following samples were taken (Fig. 2):

6/1 Alaskite type granite

6/2 Pegmatite with black mica

6/3 Feldspar-quartz pegmatite, hematized surfaces

6/4 Feldspar pegmatite with some garnets, 5-8 $\mathrm{mm}$ in diameter, and molybdenite flakes 


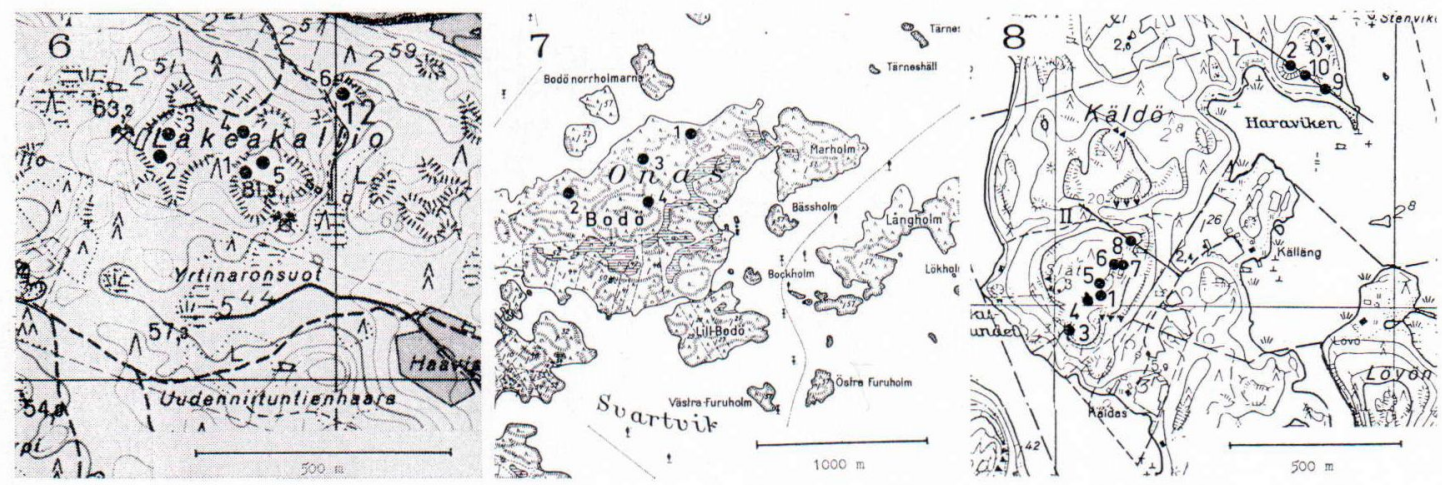

Fig. 2. Detail maps of sampling sites in Askola (6), Bodö (7), and Källdö (8). Copyright 1974 by Maanmittaushallitus, Helsinki.

$6 / 5$ Feldspar pegmatite with fragments of the surrounding mica gneiss

6/6 Mica gneiss

7. Porvoo parish, Bodö island (Laitala 1967). The northern part of the island is migmatitic granite bordered by a broad hornblende gneiss zone in the middle of the island. The strike of this zone is $\mathrm{N} 45^{\circ} \mathrm{E}$ and the dip almost vertical. A narrow fracturized radioactive pegmatite dike from 0.5 to $2 \mathrm{~m}$ wide, which can be observed by Geiger counter for $450 \mathrm{~m}$, runs through the migmatites parallel with the hornblende zone. The pegmatite consists mainly of coarse $(1-5$ $\mathrm{cm})$ feldspar crystals with minor amounts smoky quartz, black mica, uraninite and other black minerals as flaky inclusions in fractures. The following samples were taken (Fig. 2):

$7 / 1$ Fine-grained reddish granite about $200 \mathrm{~m}$ SE of the mineralized zone

7/2 Grey feldspar pegmatite

$7 / 3$ Reddish, hematized pegmatite

7/4 Hornblende gneiss

8. Pernaja, Källdö island (Vaasjoki 1953). The bedrock consists of homogeneous potash granite. The granite is cut by a mylonite zone from 10 to $50 \mathrm{~m}$ wide. The zone strikes $\mathrm{N} 30^{\circ} \mathrm{E}$ and it can be observed for about $300 \mathrm{~m}$ beginning from the SW shore of the island and once more for about $50 \mathrm{~m}$ on the NE shore. The mylonite is fine- to coarse-grained and contains inclusions of the surrounding granites and supracrustal rocks. The colour varies from black to red owing to hematization. Many parts of the mylonitized zone contain uraninite as thin layers in cleavage planes causing strong radioactivity. The following samples were taken (Fig. 2):

8/1 Potash granite

8/2 Potash granite

$8 / 3$ Fine-grained hematized mylonite

8/4 Fine-grained hematized mylonite

8/5 Fine-grained dark mylonite

$8 / 6$ Fine-grained hematized mylonite

8/7 Fine-grained hematized mylonite with abundant black fracture fillings

8/8 Coarse hematized mylonite

8/9 Fine-grained hematized mylonite

8/10 Coarse dark mylonite.

\section{Analytical method}

The conventional scanning method was used (Bingham and Elliot 1971). The magnetic field is allowed to decay exponentially so that ion beams of the individual isotopic species are swept successively across the detection slit and measured with an electron multiplier. The sample homogenity is very important because 


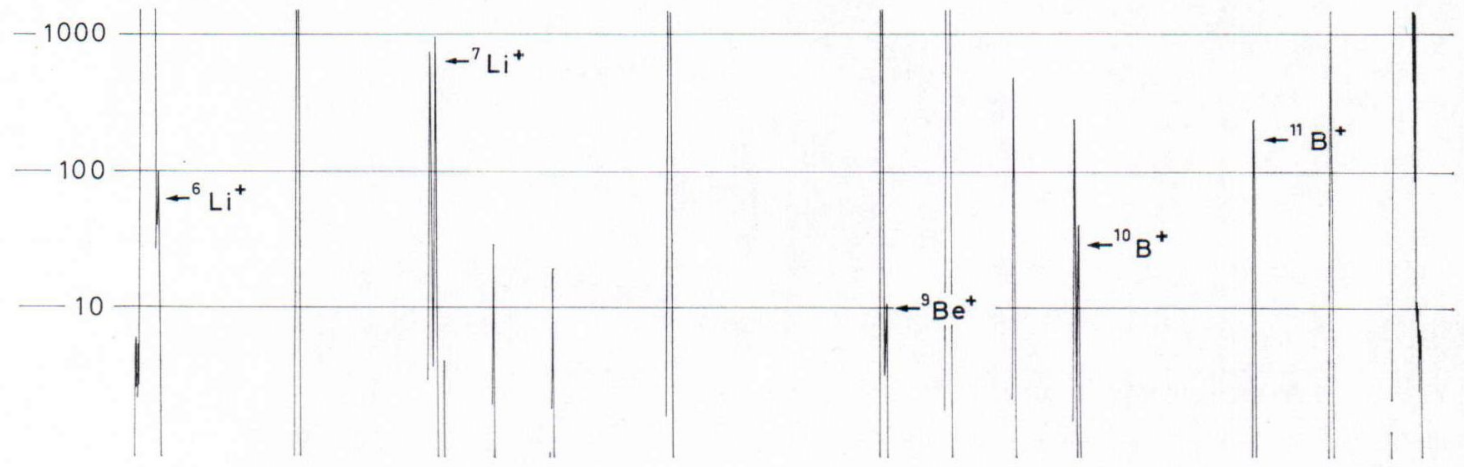

Fig. 3. Mass spectrometric scan from ${ }^{12} \mathrm{C}^{+}$to ${ }^{6} \mathrm{Li}^{+}$.

each isotopic ion beam is measured for only a short time. The outputs from the electron multiplier and the total ion beam monitor are rationed by a conventional double logarithmic amplifier in order to overcome errors caused by fluctuation of the instant total ion current. The resultant output is recorded on an ultravioletsensitive chart recorder.

Fig. 3 presents the $\mathrm{Li}-\mathrm{C}$ region of such a scan from USGS W-1. The ${ }^{6} \mathrm{Li}^{+}$peak is almost completely separated from the ${ }^{12} \mathrm{C}^{2+}$ peak, ${ }^{7} \mathrm{Li}^{+}$ from ${ }^{14} \mathrm{~N}^{2+}$ and ${ }^{10} \mathrm{~B}^{+}$from ${ }^{30} \mathrm{Si}^{3+}$. Thus, the resolving power is about 800 . With photoplate detection, the $\mathrm{m} / \mathrm{e}$ lines at mass numbers $6,7,9$ and 10 were unusable owing to overlap from ${ }^{12} \mathrm{C}^{2+},{ }^{11} \mathrm{~N}^{2+},{ }^{27} \mathrm{Al}^{3+}$ and ${ }^{30} \mathrm{Si}^{3+}$, respectively.

With chosen amplifier and electron multiplier gains a concentration range of $1: 1000$ is measurable on the three-decade logarithmic scale. In the present study, the detection limit was about $1 \mathrm{ppm}$ depending on the atomic weight and isotopic abundance of the interference free isotopes. No attempt was made to lower the detection limit because we wanted to determine elements occuring in higher contents with the same scans.

\section{Collection and preparation of samples}

The sample size was from 1 to $2 \mathrm{~kg}$ and attempts were made to obtain samples typical of the formations in respect to the main mineral assemblage. The samples from the pegmatitic deposits in particular are by no means representative of the radioactive mineralization which occurs very much at random in spots and shoots.

The samples were first broken by hammer so that all material passed through a $1 / 2^{\prime \prime}$ screen. The product was then successively quartered and crushed by hard metal mortar until it weighed $10 \mathrm{~g}$ and was $1 \mathrm{~mm}$ in grain size. Finally, it was milled for one hour in a $50 \mathrm{~cm}^{3}$ agate mill (Pulverisette 6 from A. Fritsch OHG) employing three agate balls, $20 \mathrm{~mm}$ in diameter. The finess of the milled product was as follows: $-37 \mu 99.1 \%,-32 \mu 98.2 \%,-20 \mu 86.1 \%$ and $-15 \mu 70.1 \%$.

Rhenium was chosen as the internal standard element. Ringsdorff RW A graphite was doped with $100 \mathrm{ppm} \operatorname{Re}$ as follows: one millilitre of a solution containing $100 \mathrm{ppm} \mathrm{Re}$ as $\mathrm{KReO}_{4}$ was mixed with $1 \mathrm{~g}$ of graphite powder; $0.5 \mathrm{ml}$ of ethanol was added as a wetting agent, and the mixture was ground in an agate mortar until dry. Ten mixtures were made and then milled together in the agate mill for one hour.

USGS standards G-1 and W-1 were used as external standards (Fleischer 1969 and Flanagan 1973). The electrodes were made by the usual polythene slug technique. $150 \mathrm{mg}$ of milled rock and $150 \mathrm{mg}$ of the doped graphite powder were 
ground by hand in an agate mortar for 20 minutes.

\section{Mass spectrometric scanning}

The instrument and the operating parameters are presented in Table 1. The spark parameters and the position of the electrodes in the source chamber greatly influence the intensity of the spectrum lines. Therefore, the spark parameters were kept constant and great care was taken in loading the electrodes. The Autospark (Bingham and Elliot 1971) was used in order to maintain a constant electrode gap. The position of the electrodes was corrected manually during scanning, because the wearing of the electrodes gradually deflects the ion beam from the optical axis. All the samples were scanned at least three times. The standard samples were scanned 9 times.

TABLE 1. Instrument and operating parameters

Instrument: Double focusing mass spectrometer MS 702, Ratio amplifier and Autospark unit (Associated Electrical Industries)

Spark voltage: $30 \mathrm{kV}$

Pulse frequence: $1000 \mathrm{~Hz}$

Pulse length: $\quad 25 \mu \mathrm{s}$

Accelerating voltage:

$19.5 \mathrm{kV}$

Range of magnetic current scanned: $220-20 \mathrm{~mA}$ (U-Li) Time constant of the scanning: $600 \mathrm{~s}$, about $20 \mathrm{~min} / \mathrm{scan}$ Pressure in source area: $10^{-4}$ Torr

Pressure in analyzer: $3 \times 10^{-9}$ Torr

Recorder: Oscillograph 3006/DL (SE Laboratories Ltd)

\section{Precision}

The precision of the scanning was tested on the standard granite G-1 and sample 1 (rapakivi from Lapinjärvi) by means of cyclic scanning. G-1 was scanned 11 times and sample 122 times back and forth from cesium to neodymium. The standard deviations of the means of the peak heights were from 6.7 to $14.8 \%$ for $\mathrm{G}-1$ and from 6.8 to $12.7 \%$ for sample 1 (Table 2).
Table 2

Relative standard deviation of the means of peak heights

\begin{tabular}{|c|c|c|c|c|c|}
\hline \multirow[b]{2}{*}{ Isotope } & \multirow{2}{*}{$\begin{array}{c}\text { G-1 } \\
\begin{array}{c}11 \text { scans } \\
\text { with one } \\
\text { electrode } \\
\text { pair }\end{array} \\
\%\end{array}$} & \multirow{2}{*}{$\begin{array}{c}\text { Sample 1 } \\
22 \text { scans } \\
\text { with one } \\
\text { electrode } \\
\text { pair } \\
\%\end{array}$} & \multicolumn{3}{|c|}{$\begin{array}{l}\text { Sample } 8 / 627 \text { scans } \\
\text { with } 9 \text { electrode pairs }\end{array}$} \\
\hline & & & $\%$ & Isotope & $\%$ \\
\hline${ }^{133} \mathrm{Cs}^{+}$ & 10.6 & 6.8 & 14.2 & ${ }^{85} \mathrm{Rb}^{+}$ & 7.1 \\
\hline${ }^{134} \mathrm{Ba}^{+}$ & 6.7 & 8.7 & 9.8 & ${ }^{86} \mathrm{Sr}^{+}$ & 8.2 \\
\hline${ }^{135} \mathrm{Ba}^{+}$ & 9.7 & 6.9 & 9.0 & ${ }^{88} \mathrm{Sr}^{+}$ & 7.5 \\
\hline${ }^{136} \mathrm{Ba}^{+}$ & 8.6 & 7.7 & 13.0 & ${ }^{89} \mathrm{Y}^{+}$ & 9.1 \\
\hline${ }^{137} \mathrm{Ba}^{+}$ & 8.2 & 8.4 & 11.3 & ${ }^{90} \mathrm{Zr}^{+}$ & 9.5 \\
\hline${ }^{139} \mathrm{La}^{+}$ & 12.1 & 10.4 & 18.1 & ${ }^{91} \mathrm{Zr}^{+}$ & 9.2 \\
\hline${ }^{140} \mathrm{Ce}^{+}$ & 7.3 & 10.1 & 8.1 & ${ }^{93} \mathrm{Nb}^{+}$ & 14.3 \\
\hline${ }^{141} \mathrm{Pr}^{+}$ & 14.8 & 12.4 & 12.1 & ${ }^{206} \mathrm{~Pb}^{+}$ & 8.5 \\
\hline${ }^{143} \mathrm{Nd}^{+}$ & 14.1 & 12.4 & 11.0 & ${ }^{207} \mathrm{~Pb}^{+}$ & 9.0 \\
\hline${ }^{145} \mathrm{Nd}^{+}$ & 12.4 & 12.7 & 15.2 & ${ }^{208} \mathrm{~Pb}^{+}$ & 7.2 \\
\hline${ }^{185} \mathrm{Re}^{+}$ & 7.2 & - & 11.2 & ${ }^{232} \mathrm{Th}^{+}$ & 9.6 \\
\hline${ }^{187} \mathrm{Re}^{+}$ & 6.6 & - & 13.8 & ${ }^{238} \mathrm{U}^{+}$ & 10.0 \\
\hline
\end{tabular}

In order to study the effect of sample preparation and electrode positioning on precision, 9 pairs of electrodes were made from mixtures prepared separately of sample $7 / 1$ (granite from Bodö) and graphite. Each pair of electrodes was scanned 3 times with exponential scanning from uranium to rubidium. The standard deviations of the means of the peak heights were from 7.1 to $18.1 \%$ (Table 2 ). As a rule the precision was slightly lower than that obtained with one pair of electrodes.

\section{Results}

The ratio peak height/content (ppm in weight) in the standard is presented in Table 3 for W-1 and G-1. Almost all measurable lines were included in this table. On the whole the values are in good agreement with each other in spite of the different chemical compositions of the standards. In most of the lines the error, when calculated as the percentage of difference from the smaller value, is less than $20 \%$. The large error in ${ }^{6} \mathrm{Li}^{+}(26 \%)$ and in ${ }^{10} \mathrm{~B}+(48 \%)$ is caused by incomplete resolution ( $c f$. Fig. 3). On the basis of results presented in Table 3 , it can be estimated that the accuracy is generally better than $\pm 20 \%$. The trace element contents in th 
TABLE 3

Peak height/content (ppm) in W-1 and G-1

\begin{tabular}{|c|c|c|c|c|c|c|c|c|}
\hline Isotope & $W-1$ & G-1 & Isotope & $W-1$ & G-1 & Isotope & W-1 & $G-1$ \\
\hline${ }^{6} \mathrm{Li}^{+} \ldots \ldots \ldots$ & 5.8 & 4.6 & ${ }^{65} \mathrm{Cu}^{+}+\ldots \ldots \ldots$ & 1.3 & 1.3 & ${ }^{143} \mathrm{Nd}^{+} \ldots \ldots \ldots$ & 0.37 & 0.39 \\
\hline${ }^{7} \mathrm{Li}+\ldots \ldots \ldots$ & 62.5 & 62.5 & ${ }^{85} \mathrm{Rb}^{+} \ldots \ldots \ldots$ & 12.4 & 一 & ${ }^{145} \mathrm{Nd}^{+} \ldots \ldots \ldots$ & 0.32 & 0.31 \\
\hline${ }^{9} \mathrm{Be}^{+} \ldots \ldots \ldots$ & 14.4 & 13.3 & ${ }^{85} \mathrm{Rb}^{2+} \ldots \ldots \ldots$ & 0.083 & 0.095 & ${ }^{147} \mathrm{Sm}^{+} \ldots \ldots \ldots$ & 0.47 & 0.42 \\
\hline${ }^{10} \mathrm{~B}^{+} \ldots \ldots \ldots$ & 2.7 & 4.0 & ${ }^{86} \mathrm{Sr}^{+} \ldots \ldots \ldots$ & 0.60 & 0.52 & ${ }^{149} \mathrm{Sm}^{+} \ldots \ldots \ldots$ & 0.45 & 0.48 \\
\hline${ }^{11} \mathrm{~B}+\ldots \ldots \ldots$ & 16.0 & 16.0 & ${ }^{89} \mathrm{Y}+\ldots \ldots \ldots$ & 1.9 & 1.7 & ${ }^{151} \mathrm{Eu}^{+} \ldots \ldots \ldots$ & 2.24 & 3.08 \\
\hline${ }^{19} \mathrm{~F}+\ldots \ldots \ldots$ & 1.4 & 1.5 & ${ }^{89} \mathrm{Y}^{2+} \ldots \ldots \ldots$ & 0.22 & 0.20 & ${ }^{153} \mathrm{Eu}^{+} \ldots \ldots \ldots$ & 2.38 & 2.78 \\
\hline${ }^{19} \mathrm{~F}^{2}+\ldots \ldots \ldots$ & 0.02 & 0.02 & ${ }^{90} \mathrm{Z}_{\mathrm{r}^{+}} \ldots \ldots \ldots$ & 1.67 & 1.54 & ${ }^{157} \mathrm{Gd}+\ldots \ldots \ldots$ & 0.52 & 0.64 \\
\hline${ }^{23} \mathrm{Na}^{2}+\ldots \ldots \ldots$ & 0.04 & 0.03 & ${ }^{91} \mathrm{Zr}^{+} \ldots \ldots \ldots$ & 0.33 & 0.24 & ${ }^{158} \mathrm{Gd}+\ldots \ldots \ldots$ & 0.77 & 0.68 \\
\hline${ }^{25} \mathrm{Mg}^{2}+\ldots \ldots$ & - & 0.26 & ${ }^{91} \mathrm{Zr}^{2}+\ldots \ldots \ldots$ & 0.07 & 0.06 & ${ }^{159} \mathrm{~Tb}^{+} \ldots \ldots \ldots$ & 3.11 & 3.33 \\
\hline${ }^{31} \mathrm{p}^{2}+\ldots \ldots \ldots \ldots$ & 1.1 & 1.0 & ${ }^{93} \mathrm{Nb}^{+} \ldots \ldots \ldots$ & 1.60 & 1.72 & ${ }^{161} \mathrm{Dy}^{+} \ldots \ldots \ldots$ & 0.58 & 0.56 \\
\hline${ }^{35} \mathrm{Cl}+\ldots \ldots \ldots$ & - & 4.0 & ${ }^{93} \mathrm{Nb}^{2}+\ldots \ldots \ldots$ & 0.25 & 0.26 & ${ }^{163} \mathrm{Dy}^{+} \ldots \ldots \ldots$ & 0.65 & 0.64 \\
\hline${ }^{35} \mathrm{Cl}^{2}+\ldots \ldots \ldots$ & 0.45 & 0.43 & ${ }^{97} \mathrm{Mo}^{+} \ldots \ldots$ & - & 0.36 & ${ }^{165} \mathrm{Ho}^{+} \ldots \ldots \ldots$ & 3.0 & 3.2 \\
\hline${ }^{37} \mathrm{Cl}+\ldots \ldots \ldots$ & - & 2.1 & ${ }^{98} \mathrm{Mo}^{+} \ldots \ldots \ldots$ & 一 & 0.64 & ${ }^{166} \mathrm{Er}^{+} \ldots \ldots \ldots$ & 1.1 & 0.90 \\
\hline${ }^{37} \mathrm{Cl}^{2}+\ldots \ldots \ldots$ & 0.15 & 0.13 & ${ }^{100} \mathrm{Mo}^{+} \ldots \ldots \ldots$ & - & 0.37 & ${ }^{167} \mathrm{Er}^{+} \ldots \ldots \ldots$ & 0.80 & 0.60 \\
\hline${ }^{41} \mathrm{~K}^{2}+\ldots \ldots \ldots$ & 0.015 & 0.011 & ${ }^{117} \mathrm{Sn}^{+}+\ldots \ldots \ldots$ & 0.25 & 0.27 & ${ }^{169} \mathrm{Tm}^{+} \ldots \ldots \ldots$ & 3.6 & - \\
\hline${ }^{43} \mathrm{Ca}^{2}+\ldots \ldots \ldots$ & 0.0028 & 0.0031 & ${ }^{118} \mathrm{Sn}^{+} \ldots \ldots \ldots$ & 0.85 & 0.83 & ${ }^{121} \mathrm{Yb}^{+}+\ldots \ldots \ldots$ & 0.43 & - \\
\hline${ }^{45} \mathrm{Sc}^{2}+\ldots \ldots \ldots$ & 0.59 & 0.63 & ${ }^{119} \mathrm{Sn}^{+} \ldots \ldots \ldots$ & 0.32 & 0.30 & ${ }^{172} \mathrm{Yb}^{+}+\ldots \ldots \ldots$ & 0.61 & - \\
\hline${ }^{47} \mathrm{Ti}^{+}+\ldots \ldots \ldots$ & - & 0.64 & ${ }^{121} \mathrm{Sb}^{+} \ldots \ldots \ldots$ & 1.48 & 1.21 & ${ }^{174} \mathrm{Yb}^{+} \ldots \ldots \ldots$ & 1.05 & - \\
\hline${ }^{47} \mathrm{Ti}^{2}+\ldots \ldots \ldots$ & 0.051 & 0.040 & ${ }^{133} \mathrm{Cs}+\ldots \ldots \ldots$ & 9.6 & 11.3 & ${ }^{175} \mathrm{Lu}^{+} \ldots \ldots \ldots$ & 2.87 & - \\
\hline${ }^{49} \mathrm{Ti}^{+} \ldots \ldots \ldots$ & - & 0.36 & ${ }^{134} \mathrm{Ba}^{+} \ldots \ldots \ldots$ & 0.10 & 0.095 & ${ }^{177} \mathrm{Hf}^{+} \ldots \ldots \ldots$ & 0.55 & 0.57 \\
\hline${ }^{49} \mathrm{Ti}^{2}+\ldots \ldots \ldots$ & 0.03 & 0.03 & ${ }^{135} \mathrm{Ba}^{+} \ldots \ldots \ldots$ & 0.37 & 0.32 & ${ }^{178} \mathrm{Hf}^{+} \ldots \ldots \ldots$ & 0.65 & 0.78 \\
\hline${ }^{51} \mathrm{~V}+\ldots \ldots \ldots$ & - & 5.9 & ${ }^{135} \mathrm{Ba}^{2}+\ldots \ldots \ldots$ & 0.039 & 0.040 & ${ }^{181} \mathrm{Ta}^{+} \ldots \ldots \ldots$ & 1.67 & 1.45 \\
\hline${ }^{51} \mathrm{~V}^{2}+\ldots \ldots \ldots$ & 0.28 & 0.31 & ${ }^{136} \mathrm{Ba}^{+} \ldots \ldots \ldots$ & 0.42 & 0.39 & ${ }^{203} \mathrm{Tl}+\ldots \ldots \ldots$ & - & 1.69 \\
\hline${ }^{55} \mathrm{Mn}^{+} \ldots \ldots \ldots$ & - & 5.2 & ${ }^{137} \mathrm{Ba}^{+} \ldots \ldots \ldots$ & 0.49 & 0.47 & ${ }^{205} \mathrm{Tl}+\ldots \ldots \ldots$ & - & 3.62 \\
\hline${ }^{55} \mathrm{Mn}^{2}+\ldots \ldots \ldots$ & 一 & 0.36 & ${ }^{137} \mathrm{Ba}^{2}+\ldots \ldots \ldots$ & 0.048 & 0.050 & ${ }^{206} \mathrm{~Pb}^{+} \ldots \ldots \ldots$ & 0.55 & 0.51 \\
\hline${ }^{57} \mathrm{Fe}^{2}+\ldots \ldots \ldots$ & 0.004 & 0.006 & ${ }^{139} \mathrm{La}^{+} \ldots \ldots \ldots$ & 2.0 & 2.0 & ${ }^{207} \mathrm{~Pb}^{+}+\ldots \ldots \ldots$ & 0.46 & 0.44 \\
\hline${ }^{59} \mathrm{Co}^{+} \ldots \ldots \ldots$ & 6.0 & - & ${ }^{139} \mathrm{La}^{2}+\ldots \ldots \ldots$ & 0.26 & 0.26 & ${ }^{208} \mathrm{~Pb}^{+} \ldots \ldots \ldots$ & 0.94 & 0.97 \\
\hline${ }^{59} \mathrm{Co}^{2+} \ldots \ldots \ldots$ & 0.18 & - & ${ }^{140} \mathrm{Ce}^{+} \ldots \ldots \ldots \ldots$ & 1.8 & 1.7 & ${ }^{209} \mathrm{Bi}^{+} \ldots \ldots \ldots$ & - & 1.11 \\
\hline${ }^{63} \mathrm{Cu}^{+} \ldots \ldots \ldots$ & 2.7 & 2.4 & ${ }^{141} \operatorname{Pr}^{+} \ldots \ldots$ & 1.9 & 2.0 & ${ }^{232} \mathrm{Th}^{+} \ldots \ldots \ldots$ & 0.93 & 0.92 \\
\hline${ }^{63} \mathrm{Cu}^{2}+\ldots \ldots$ & 0.15 & 二 & ${ }^{141} \mathrm{Pr}^{2}+\ldots \ldots \ldots$ & 0.33 & 0.33 & ${ }^{238} \mathrm{U}^{+} \ldots \ldots \ldots$ & 2.39 & 2.31 \\
\hline
\end{tabular}

samples were determined by comparing the peak heights of the samples with those of the standards. The peak heights were corrected separately with intensity ratios of ${ }^{185} \mathrm{Re}^{+}$and ${ }^{187} \mathrm{Re}^{+}$in sample and standard, respectively, and the average was taken. In samples scanned in quick succession the peak heights of the rhenium isotopes were almost always constant, but over long periods the sensitivity of the instrument gradually changed. The results are presented in Table 4.

The contents of $\mathrm{Cl}, \mathrm{V}, \mathrm{Rb}$ and $\mathrm{Sc}$ were determined with double charged lines. The $\mathrm{Cl}$ and $\mathrm{V}$ contents in $\mathrm{W}-1$ were so hight that single charged lines were too strong to be measured, as was the $\mathrm{Rb}$ content in G-1. The single charged line of Sc was strongly influenced by ${ }^{90} \mathrm{Zr}^{2+}$. The Ta content was determined in spite of possible contamination from the source, because of no obvious erraneous intensities were apparent.

The lead content was calculated as the average of the results from $\mathrm{Pb}$ isotopes 206, 207 and 208, when the isotopic ratios were normal. However, in all the samples from Askola, Bodö, and Källdö the isotopic abundances were influenced by the radiogenic lead. Some examples are presented in Table 5. The lead content in these samples was determined by comparing the intensity sum of $\mathrm{Pb}$ isotopes 206, 207, 208 with the corresponding sum of $\mathrm{G}-1$. These results were verified by $\mathrm{X}$-ray fluorescence and they agreed within $\pm 10 \%$.

The As content was below $5 \mathrm{ppm}$ in all samples, and that of Sb $2 \mathrm{ppm}$ at the most. As expected, the Mo content (Laitakari and Simonen 1963), was higher in samples from Askola. The 
TABLE 4

Trace element content ( $\mathrm{ppm}$ ) of rock samples determined by spark source mass spectrometry. Dash indicates content below detection limit and $\gg$ content too high to be determined with the operating parameters used.

\begin{tabular}{|c|c|c|c|c|c|c|c|c|c|c|c|c|c|c|c|c|c|c|c|c|c|c|}
\hline No & Name & Site & & $\mathrm{Li}$ & $\mathrm{Be}$ & B & F & $P$ & $\mathrm{Cl}$ & Sc & $\mathrm{Ti}$ & V & Co & $\mathrm{Cu}$ & $\mathrm{Rb}$ & $\mathrm{Sr}$ & $\mathrm{Y}$ & $\mathrm{Zr}$ & $\mathrm{Nb}$ & Sn & Cs & $\mathrm{Ba}$ \\
\hline 1 & Rapakivi & Lapinjä & järvi & 50 & 0.5 & 7.5 & 3900 & 330 & 740 & 25 & 2300 & 6.5 & 35 & 20 & 190 & 170 & 150 & 380 & 45 & 5 & 20 & 2200 \\
\hline 2 & Granite & Onas. & $\ldots$ & 140 & 2.1 & 3.5 & 2100 & 70 & 180 & - & 1000 & 2.5 & 14 & 10 & 80 & 220 & 130 & 100 & 25 & 7 & 0.4 & 2000 \\
\hline 3 & Granite & Bodom & $\mathrm{m} \ldots$ & 140 & 7.0 & 2.5 & 3700 & 50 & 730 & 25 & 2600 & 2.5 & 16 & 5.5 & 220 & 60 & 180 & 190 & 70 & 9.0 & 1.0 & 720 \\
\hline \multirow{2}{*}{$\begin{array}{l}4 \\
5\end{array}$} & Granite & Kuivas & saari & 20 & 5.0 & 5.5 & 180 & 30 & 60 & - & 2300 & 3.0 & 10 & 5.5 & 14 & 90 & 80 & 110 & 25 & 5.0 & 0.5 & 200 \\
\hline & Granite & $\begin{array}{l}\text { Käärm } \\
\text { saari . . }\end{array}$ & $\begin{array}{l}n e- \\
\ldots \ldots\end{array}$ & 7 & 3.4 & 5.0 & 190 & 40 & 60 & 17 & 2000 & 6.0 & 一 & 3.0 & 95 & 120 & 17 & 250 & 11 & - & 0.6 & 800 \\
\hline $6 / 1$ & Granite & Askola & $a \ldots$ & 7 & 0.8 & 7.0 & 250 & 140 & 30 & 50 & 45 & 5.5 & - & 1.4 & 120 & 240 & 100 & 90 & 7.0 & 一 & 12 & 950 \\
\hline $6 / 2$ & Pegmatite & $"$ & . . & 13 & 8.5 & 20 & 50 & 70 & 10 & 7.5 & 1500 & 7.0 & 3.5 & 1.5 & 30 & 190 & 140 & 400 & 14 & - & 3.2 & 200 \\
\hline $6 / 3$ & Pegmatite & $"$ & $\ldots$ & 150 & 4.2 & 8.0 & 400 & 130 & 200 & 9.0 & 4400 & 130 & 20 & 30 & 270 & 330 & 140 & 250 & 20 & 26 & 22 & 120 \\
\hline $6 / 4$ & Pegmatite & $"$ & . . & 一 & 1.5 & 14 & 290 & 1200 & 40 & 500 & 220 & 26 & 8.0 & 6.5 & 75 & 130 & 540 & 20 & 3.1 & 14 & 2.0 & 900 \\
\hline $6 / 5$ & Pegmatite & $"$ & . & 60 & 0.5 & 4.0 & 1300 & 360 & 230 & 280 & 2500 & 45 & 20 & 270 & 150 & 140 & 230 & 50 & 16 & 7.5 & 6.5 & 90 \\
\hline $6 / 6$ & Mica gneiss & $"$ & . & 100 & 2.0 & 3.5 & 800 & 340 & 160 & 60 & 6700 & 50 & 10 & 6.0 & 130 & 200 & 33 & 80 & 20 & 9.5 & 14 & 650 \\
\hline \multirow{4}{*}{$\begin{array}{l}7 / 1 \\
7 / 2 \\
7 / 3 \\
7 / 4\end{array}$} & Granite & Bodö . & $\ldots$ & 5 & 6.0 & 10 & 570 & 800 & 80 & 40 & 500 & 30 & 8.0 & 3.5 & 70 & 200 & 110 & 120 & 30 & 5.0 & 5.0 & 230 \\
\hline & Pegmatite & $»$. & $\ldots \ldots$ & 11 & 6.5 & 7.5 & 280 & 300 & 90 & 40 & 750 & 4.0 & 2.0 & 15 & 90 & 200 & 860 & 30 & 70 & 16 & 5.0 & 130 \\
\hline & Pegmatite & $"$ & $\ldots \ldots$ & 30 & 3.3 & 6.0 & 3500 & 600 & 400 & 80 & 4300 & 35 & 7.0 & 35 & 400 & 120 & 520 & 270 & 150 & 30 & 21 & 320 \\
\hline & $\begin{array}{l}\text { Hornblende } \\
\text { gneiss }\end{array}$ & $"$ & & 15 & 2.2 & 8.0 & 1200 & 150 & 100 & 140 & 4000 & 120 & 60 & 13 & 110 & 180 & 23 & 24 & 5.0 & - & 1.6 & 510 \\
\hline $8 / 1$ & Granite & \multicolumn{2}{|c|}{ Källdö . } & 30 & 4.0 & 3.0 & 210 & 75 & 120 & 30 & 950 & 5.0 & 一 & 8.0 & 210 & 40 & 40 & 130 & 50 & 一 & 8.5 & 330 \\
\hline $8 / 2$ & Granite & " & $\ldots$ & 35 & 3.6 & 2.6 & 160 & 130 & 70 & - & 950 & 17 & - & 4. 0 & 160 & 90 & 35 & 49 & 65 & - & 2.3 & 160 \\
\hline $8 / 3$ & Mylonite & $"$ & $\ldots$ & 95 & 4.0 & 16 & 440 & 260 & 40 & - & 1200 & 80 & 4.5 & 13 & 170 & 1000 & 45 & 180 & 40 & 5.5 & 3.3 & 1800 \\
\hline $8 / 4$ & Mylonite & $»$ & $\ldots$ & 130 & 8.5 & 23 & 720 & 250 & 100 & 一 & 1300 & 40 & 4.0 & 3.5 & 450 & 400 & 22 & 110 & 23 & 5.5 & 3.6 & 960 \\
\hline $8 / 5$ & Mylonite & $»$ & $\ldots$ & 15 & 0.5 & 13 & 380 & 270 & 120 & - & 200 & 9.0 & 3.0 & 7.5 & 900 & 180 & 10 & 6.0 & 6.0 & - & 4.5 & 780 \\
\hline $8 / 6$ & Mylonite & $»$ & $\ldots$ & 90 & 12 & 45 & 460 & 100 & 30 & 70 & 4000 & 35 & 2.0 & 120 & 570 & 200 & 22 & 100 & 17 & 4.0 & 4.0 & 2300 \\
\hline $8 / 7$ & Mylonite & $»$ & $\ldots$ & 40 & 12 & 50 & 720 & 530 & 60 & - & 4500 & 80 & 20 & 25 & 500 & 420 & 19 & 200 & 30 & - & 8.5 & 2000 \\
\hline $8 / 8$ & Mylonite & $"$ & $\ldots$ & 17 & 11 & 75 & 320 & 80 & 40 & 35 & 2200 & 25 & 3.0 & 60 & 540 & 300 & 50 & 280 & 20 & - & 14 & 2300 \\
\hline $8 / 9$ & Mylonite & $»$ & $\ldots$ & 70 & 7.0 & 60 & 1500 & 120 & 130 & 100 & 30000 & 100 & 16 & 25 & 40 & 110 & 50 & 200 & 10 & 4.5 & 4.0 & 400 \\
\hline $8 / 10$ & Mylonite & $"$ & $\ldots$ & 20 & 2.0 & 3.5 & 200 & $》$ & 75 & 60 & 21000 & 100 & 14 & 10 & 370 & 220 & 20 & 140 & 27 & 5.5 & 4.1 & 470 \\
\hline & $G-1 \ldots$ & & & 22 & 3.0 & 1.7 & 690 & 390 & 70 & 2.9 & 1560 & 16 & 2.4 & 13 & 220 & 250 & 13 & 210 & 23.5 & 3.5 & 1.5 & 1200 \\
\hline & $\mathrm{W}-1 \ldots \ldots$ & & & 14.5 & 0.80 & 15 & 250 & 470 & 200 & 55.1 & 6400 & 264 & 47 & 110 & 21 & 190 & 25 & 105 & 9.5 & 3.2 & 0.9 & 160 \\
\hline & Detection lir & mit . . & & 0.1 & 0.5 & 1 & 10 & 10 & 5 & 6 & 10 & 2 & 2 & 1 & 0.5 & 6 & 1.5 & 5 & 2 & 3 & 0.3 & 10 \\
\hline
\end{tabular}




\begin{tabular}{|c|c|c|c|c|c|c|c|c|c|c|c|c|c|c|c|c|c|c|c|c|c|c|c|}
\hline No & Name & Site & $\mathrm{La}$ & $\mathrm{Ce}$ & $\operatorname{Pr}$ & $\mathrm{Nd}$ & $\mathrm{Sm}$ & $\mathrm{Eu}$ & $\mathrm{Gd}$ & $\mathrm{Tb}$ & Dy & Ho & Er & $\mathrm{Tm}$ & $\mathrm{Yb}$ & $\mathrm{Lu}$ & $\mathrm{Hf}$ & $\mathrm{Ta}$ & $\mathrm{Tl}$ & $\mathrm{Pb}$ & $\mathrm{Bi}$ & Th & $\mathrm{U}$ \\
\hline 1 & Rapakivi & Lapinjärvi & 85 & 240 & 19 & 55 & 8 & 1.1 & 14 & 2.0 & 4.5 & 0.5 & 3.5 & 0.5 & 2.6 & 0.3 & 7.5 & 2.0 & 0.7 & 40 & - & 45 & 3.2 \\
\hline 2 & Grani & Onas .... & 90 & 160 & 30 & 80 & 20 & & 20 & 2 & 5.7 & 1 & 3.1 & - & 4.9 & 0.3 & 1.4 & 1.0 & 0.8 & 35 & - & 18 & 3.7 \\
\hline 3 & Granite & Bodom ... & 560 & 600 & 170 & 330 & 60 & 2.0 & 40 & 5.1 & 13 & 1.5 & 5.8 & 0.5 & 3.1 & 0.9 & 3.8 & 1.4 & 1.7 & 50 & - & 70 & 4.0 \\
\hline 4 & Granite & Kuivasaari & 110 & 140 & 30 & 55 & 14 & 1.9 & 6.1 & 1.5 & 3.5 & 1.2 & 6.3 & 0.3 & 2.5 & 0.4 & 3.0 & - & - & 20 & - & 7.3 & 2.8 \\
\hline 5 & Granite & $\begin{array}{l}\text { Käärme- } \\
\text { saari ..... }\end{array}$ & 40 & 60 & 10 & 20 & 5.5 & 1.0 & 3.2 & 0.9 & 4.6 . & - & 1.5 & - & - & & 一 & 一 & 0.5 & 24 & - & 8.1 & 3.9 \\
\hline $6 / 1$ & Granite & Askola ... & 11 & 16 & 1.0 & - & - & 一 & - & - & 4.0 & 一 & 1.7 & 0.6 & 1.5 & 0.7 & - & 一 & 1.5 & 120 & 一 & 27 & 45 \\
\hline $6 / 2$ & Pegm & " & 100 & 220 & 35 & 80 & 11 & 1.0 & 6.0 & 1.2 & 3.4 & - & 二 & - & - & - & - & - & 1.2 & 100 & - & 190 & 130 \\
\hline $6 / 3$ & Pegm & $\ldots$ & 410 & 800 & 90 & 190 & 40 & 1. & 13 & 2.8 & 16 & 2.3 & 3.0 & - & 3.0 & - & 6.0 & 1.2 & 1.6 & 180 & 2.1 & 950 & 130 \\
\hline $6 / 4$ & Pegm & $\ldots$ & 200 & 430 & 60 & 130 & 24 & 1. & 14 & 5. & 25 & 7.5 & 55 & 5.7 & 60 & 7.7 & 4.1 & - & 0.7 & 120 & - & 200 & 150 \\
\hline $6 / 5$ & Pegn & » & 50 & 150 & 16 & 55 & 5.0 & 1. & 4. 0 & 1. & 3.6 & 1.5 & 8.0 & 1. & 5.7 & 2.0 & 5.2 & 1.6 & 1.3 & 85 & - & 55 & 120 \\
\hline $6 / 6$ & Mica gneiss & . & 410 & 200 & 24 & 40 & 7.7 & 1.4 & 4.2 & 1.2 & 3.4 & 2.0 & 8.1 & 1.2 & 1.5 & - & - & 1.4 & 2.3 & 35 & - & 14 & 7.5 \\
\hline $7 / 1$ & Granite & Bodö .... & 15 & 40 & 3.0 & 20 & 10 & 一 & 7.5 & 1.0 & 5.5 & 0.5 & 2.1 & - & 2.5 & 0.3 & 2.1 & - & 0.5 & 35 & 2.0 & 14 & 17 \\
\hline $7 / 2$ & Peg & $» \quad \ldots$ & 450 & 900 & 140 & 440 & 120 & - & 702 & 23 & 65 & 9.0 & 27 & 2.0 & 6.2 & 1.1 & - & 2.6 & - & 300 & 2.1 & 790 & 560 \\
\hline $\begin{array}{l}7 / 3 \\
7 / 4\end{array}$ & Pegmatite & $\ldots$ & 480 & 1100 & 200 & 490 & 110 & 1.0 & 65 & 22 & 40 & 5.4 & 35 & 1.4 & 5.0 & 1.0 & 5.1 & 2.8 & 4.4 & 150 & - & 2000 & 85 \\
\hline & $\begin{array}{l}\text { Hornbl } \\
\text { gneiss }\end{array}$ & $»$ & 10 & 13 & 6.1 & 8.3 & 4.3. & 一 & 8.0 & 一 & 一 & 一 & 一 & 一 & - & - & 一 & 一 & 1.2 & 12 & 3.2 & 8 & 1.4 \\
\hline $8 / 1$ & & Källdö ... & 65 & 81 & 13 & 35 & 6.2 & - & - & - & 3.5 & 0.6 & 2.6 & 一 & 一 & - & 一 & - & 2.4 & 45 & 1.0 & 60 & 17 \\
\hline $8 / 2$ & $\mathrm{Gr}$ & $" \quad \ldots$ & 26 & 60 & 11 & 70 & 11 & 1.4 & 5.5 & 1.6 & 2.0 & 1. & 1.1 & 3.6 & 一 & 一 & 一 & - & 2.2 & 70 & 12 & 35 & 22 \\
\hline $8 / 3$ & Mylc & " & 35 & 75 & 15 & 35 & 7 & 1. & 5.0 & 0. & 2.0 & 0 . & 2.2 & - & - & - & - & 1.5 & 3.5 & 190 & 10 & 50 & 1100 \\
\hline $8 / 4$ & Mylo & $\ldots$ & 45 & 75 & 16 & 28 & 6 & 1.0 & 6 & 0.7 & 2.1 & 0.8 & 2.0 & 一 & - & - & 1.7 & 1.8 & 2.1 & 360 & 12 & 3 & 1000 \\
\hline $8 / 5$ & Mylonite & $\ldots$ & 7.5 & 12 & 2.2 & 4.1 & 3.6 . & - & - & - & - & - & - & - & - & - & - & 4.6 & 0.9 & 30 & 1.5 & 0 & 60 \\
\hline $8 / 6$ & Mylonite & $\ldots$ & 45 & 85 & 24 & 35 & 5.5 & 2.8 & 6.0 & 0.6 & 4.5 & 0.5 & 1.5 & 0.7 & - & - & 一 & - & 1.1 & 120 & 4.5 & 1 & 1000 \\
\hline $8 / 7$ & Mylonite & $\ldots$ & 100 & 230 & 20 & 50 & 3.5 . & - & 3.5 & 0.7 & - & 0.5 & 1.0 & - & - & - & - & 1.2 & 2.0 & 370 & - & 45 & 2500 \\
\hline $8 / 8$ & Mylonite & $\ldots$ & 150 & 600 & 35 & 110 & 16 & 1.0 & 4. 0 & 1. & 3.0 & - & - & - & - & - & - & - & 2 & 290 & 2. & 130 & 3200 \\
\hline $8 / 5$ & Mylo & $\ldots$ & 70 & 100 & 15 & 45 & 6.0 & 1. & 3.9 & 2 & 3.0 & 0.5 & 2.9 & - & - & - & - & 1. & 2.3 & 250 & 3. & 12 & 390 \\
\hline $8 / 10$ & Mylonite & $\ldots$ & 80 & 115 & 30 & 60 & 5.1 & 2.5 & 6.3 & 1.6 & 2.0 . & - & 3.0 & 0.4 & 1.5 & - & 5.0 & 4.7 & 3.1 & 20 & 1.5 & 20 & 2.9 \\
\hline & $\mathrm{G}-1$. & & 100 & 170 & 19 & 56 & 8.3 & 1.3 & 5.0 & 0.54 & 2.4 & 0.50 & 1.15 & 0.15 & 1.06 & 0.20 & 5.2 & 1.5 & 1.24 & 4 48 & 2.0 & 50 & 3.4 \\
\hline & $\mathrm{W}-1 \ldots$ & & 9.8 & 23 & 3.4 & 15 & 3.6 & 1.11 & 4.0 & 0.65 & 4.0 & 0.69 & 2.4 & 0.30 & 2.1 & 0.35 & 0.67 & 0.50 & 0.11 & 7.8 & 0.046 & 2.42 & 0.58 \\
\hline & Detection lin & mit . & 1 & 1 & 1 & 4 & 3 & 1 & 3 & 0.5 & 2 & 0.5 & 1 & 0.3 & 1.5 & 0.3 & 1.5 & 1 & 0.5 & 2 & 1 & 1 & 0.5 \\
\hline
\end{tabular}


TABLE 5

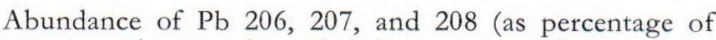
the sum intensity) in some samples

\begin{tabular}{|c|c|c|c|c|c|c|}
\hline Sample & $206 \%$ & $207 \%$ & $208 \%$ & $\mathrm{~Pb}$ ppm & U ppm & Th ppm \\
\hline G-1 & 24.8 & 21.8 & 53.4 & 48 & 3.4 & 50 \\
\hline $6 / 2 \ldots$ & 69. & 11. & 19. & 100 & 130 & 190 \\
\hline $6 / 3$ & 53.8 & 18. & 27.4 & 180 & 130 & 950 \\
\hline $6 / 6$ & 34.6 & 20.5 & 44.9 & 35 & 7.5 & 14 \\
\hline $7 / 1$ & 46.8 & 22.8 & 30.4 & 35 & 17 & 14 \\
\hline $7 / 2$ & 68.3 & 14.5 & 17.2 & 300 & 560 & 790 \\
\hline $7 / 4$ & 29.0 & 13.5 & 57.5 & 12 & 1.4 & 8 \\
\hline $8 / 3$ & 73.0 & 13.5 & 13.5 & 100 & 1100 & 50 \\
\hline $8 / 7$ & 85.2 & & 6.0 & 370 & 2500 & 45 \\
\hline $8 / 9$ & 81.3 & 10.6 & 8.1 & 260 & 390 & 12 \\
\hline
\end{tabular}

determination of low abundances is somewhat unreliable because of interfering lines and the flaky nature of $\mathrm{MoS}_{2}$, which impedes homogenization. The contents of sulphur, gallium and zinc were not determined owing to the obvious interfering lines for all possible isotopes.

$\mathrm{Cr}$ and $\mathrm{Ni}$ were not determined because of the assumed contamination during the disintegration of samples and also because of possible interfering lines. The contents of $\mathrm{Ge}, \mathrm{Se}, \mathrm{Br}$, $\mathrm{Ag}, \mathrm{Cd}, \mathrm{In}, \mathrm{Te}, \mathrm{I}, \mathrm{W}$, platinum metals, Au, and $\mathrm{Hg}$ in standards and samples were too low to be determined with the sensitivity of the method used. However, it would have been observed in the mass spectra if the contents of these elements had been higher than approximately $5 \mathrm{ppm}$. This is one advantage of this method. Another is that, at the same time, some idea can also be obtained of the contents of the main components with the aid of the double charges lines or rare isotopes. The contents of $\mathrm{Na}, \mathrm{Mg}, \mathrm{K}, \mathrm{Ca}, \mathrm{Mn}$ and $\mathrm{Fe}$ were estimated for control purposes only.

\section{Discussion}

Mass spectrometry offers an elegant approach to many geochemical problems. The number of elements that can be determined, the detection limit and the accuracy give favorable possibilities to the study of the genetic relationship of different rocks. In our investigation, for example, the contents and distribution of REE, $\mathrm{Pb}, \mathrm{Th}$, and $U$ in the rapakivi and Onas granites are very similar, which supports the view of the common origin of these anorogenic granites. On the other hand, the Bodom granite, also of anorogenic origin, has a different trace element content, the REE content in particular is higher and the $\mathrm{Ba}$ content lower. The REE content and distribution in the aforementioned granites were studied by Sahama and Vähätalo (1941) and the results, despite the very difficult pretreatment and the modest instruments available at that time, agree well with the analyses of the present study. The $\mathrm{Ba} / \mathrm{Rb}$ ratio varies also in these granites. In Bodom granite this ratio is 3.2 whereas in Onas and rapakivi granites it is over 10. According to Taylor and Heier (1960) and Tauson and Kozlov (1973), the $\mathrm{Ba} / \mathrm{Rb}$ ratio is the most informative for identification of geochemical types of granitoids and in particular of potential ore-bearing intrusives. The ratio is greatest in barren granites decreasing to one tenth and even to one 50th part in ore-bearing granites. On addition to the low $\mathrm{Ba} / \mathrm{Rb}$ ratio, the Bodom granite corresponds well according to its high $\mathrm{Li}, \mathrm{Rb}, \mathrm{Be}, \mathrm{Nb}$ and REE contents to Tawson's definition of »tin-bearing» plumasitic leucogranites. The trace element contents in the granites from Kuivasaari and Käärmesaari are similar to those of »normal» granite G-1, whereas granites which associate directly with the U, Th and REE deposits of Källdö, Bodö, and Askola have a much lower REE content, but a $U$ content that is 3 to 5 times higher than the former. More extensive investigations are necessary to solve whether the high uranium content is characteristic of these granites or whether it is a halo phenomenon.

If the analyses of the samples taken from the mineralized parts of the Bodö, Källdö and Askola deposits are compared, it can be seen that the trace element assemblage of the Källdö deposit indicates a hydrothermal formation with a high $\mathrm{Ba}$ and $\mathrm{F}$ content whereas the high contents of Th, REE, Mo and Sn in the Askola and Bodö deposits point to their formation at higher pressure and temperature (cf. Heinrich 1958). 
The different geological history of the deposits is also indicated by the almost total lack of $\mathrm{Eu}$ in the Askola and Bodö deposits despite their high content of other RE elements and the quite normal ratio Eu/REE in the Källdö deposit.

\section{REFERENCES}

Bingham, R. A. and Elliot, R. M. (1971) Accurary of analysis by electrical detection in spark source mass spectrometry. Anal. Chem. 43: 43-54.

Brown, R. and Wolstenholme, W. A. (1964) Analysis of geological samples by spark source mass spectrometry. Nature 201: 598.

Carver, R. D. and Johnson, P. G. (1968) Use of spark source mass spectrograph for the general analysis of geological samples. Appl. Spectrosc. 22: 431-433.

FLANAGAN, F. J. (1973) 1972 values for international geochemical reference samples. Geochim. Cosmochim. Acta 37: 1 189-1 200.

FLeIsCher, M. (1969) U. S. Geological survey standards- I. Additional data on rocks $\mathrm{G}-1$ and $\mathrm{W}-1$, 1965-1967. Geochim. Cosmochim. Acta 33: 65-79.

Graham, A. L. and Nicholls, C. D. (1969) Mass spectrographic determinations of lanthanide element contents in basalts. Geochim. Cosmochim. Acta 33: $555-568$.

HÄrme, M. (1969) [Map of Pre-Quaternary rocks], 2043 Kerava. General Geological Map of Finland, $1: 100000$.

Heinrich, E. W. (1958) Mineralogy and geology of radioactive raw materials. McGraw-Hill, New York: 157-161.

Laitakari, I. and Simonen, A. (1963) Kallioperäkartan selitys, 3022 Lapinjärvi. English summary: Explanation to the map of rocks. Geological map of Finland, $1: 100000.46 \mathrm{p}$.

Laitala, M. (1967) [Map of Pre-Quaternary rocks], 2034 Helsinki. General Geological Map of Finland, $1: 100000$.

Morrison, G. H. and Kashuba, A. T. (1969) Multielement analysis of basaltic rock using spark source mass spectrometry. Anal. Chem. 41: 1842 - 1846.

Morrison, G. H., Gerard, J. T., Kashuba, A. T., Ganga dharam, E. V., Rothenber G, A. M., Potter, N. M., and Miller, G B (1970) Elemental abun- dances of lunar soil and rocks. Geochim. Cosmochim Acta 34, Suppl. 1, Vol. 2: $1383-1392$.

Morrison, G. H. and Colby, B. N. (1972) Precision of electrical measurements of powdered samples in spark source mass spectrometry. Anal. Chem. 44: $1206-1210$.

Nicholls, G. D., Graham, A. L., Williams, E., and Wood, M. (1967) Precision and accuracy in trace element analysis of geological materials using solid source mass spectrography. Anal. Chem. 39: 584-590.

Sahama, Th. G., and Vähätalo, V. (1941) X-ray spectrographic study of the rare earths in some Finnish eruptive rocks and minerals. Bull. Comm. Geól. Finlande 126: 50-83.

Sederholm, J. J. (1923) On migmatites and associated pre-cambrian rocks of Southwestern Finland, Part 1. The Pellinge region. Bull. Comm. Géol. Finlande 58. $153 \mathrm{p}$.

Tauson, I. V. and Kozlov, V. D. (1973) Distribution functions and ratios of trace-element concentrations as estimators of the ore-bearing potential of granites. In Geochemical Exploration 1972, edited by M. J. Jones. Institution of Mining and Metallurgy, London: $37-44$.

Taylor, S. R. and Heier, K. S. (1960) The petrological significance of trace element variations in alkali feldspars. XXI Internat. Geol. Congress Proc., Part XIV: $47-61$.

TAYLOR, S. R. (1965 a) Geochemical application of spark source mass spectrometry. Nature 205: 34-36.

- (1965 b) Geochemical analysis by spark source mass spectrography. Geochim. Cosmochim. Acta 29: $1243-1261$.

VAAsjokr, O. (1953) On migmatites and ore mineralizations in the Pernaja district, Southern Finland. Bull. Comm. Geól. Finlande 163. 62 p.

Manuscript received, February 27, 1974. 